\title{
Initial performance of alternative citrus scion and rootstock combinations on the northern coast of the state of Bahia, Brazil
}

\author{
Maurício da Silva Amorim ${ }^{1}$, Eduardo Augusto Girardi ${ }^{2}$, Natiana de Oliveira França ${ }^{1}$, \\ Abelmon da Silva Gesteira ${ }^{2}$, Walter dos Santos Soares Filho², Orlando Sampaio Passos ${ }^{2}$
}

\begin{abstract}
The diversification of scion and rootstock varieties is tremendously necessary for the citrus industry in Northeastern Brazil. The initial performance of 13 sweet orange varieties grafted onto 'San Diego' citrandarin, and of 'Cara-Cara' navel orange and 'CNPMF-02 Persian' lime grafted onto several rootstocks was evaluated in the municipality of Inhambupe, northern coast of the state of Bahia. Three trials were carried out separately, and tree size, fruit production and quality were assessed in the first three crops, with planting in 2008 at $6.0 \mathrm{~m}$ x $3.0 \mathrm{~m}$ spacing with supplemental irrigation. 'Aquiri', 'Biondo', 'Agridoce', 'Kona', 'Pineapple', 'Russas CNPMF-03' and 'Salustiana' sweet oranges showed the largest cumulative production in the first three crops. 'Pera CNPMF D-6', 'Westin CNPMF' and 'Salustiana' sweet oranges had fewer seeds per fruit, being more appropriate for fresh fruit market, in addition to greater production efficiency for the first one. Although 'Westin CNPMF' has shown good fruit quality, its initial production was low. 'Florida' rough lemon and 'Volkamer' lemon induced higher cumulative production compared to 'Cara Cara' navel orange, but tree size and fruit quality were not influenced by any evaluated rootstock. 'Cleopatra' mandarin and 'Riverside' citrandarin led to higher tree size and cumulative production and heavier fruits of 'CNPMF-02 Persian' lime. All scion and rootstock combinations have potential for cultivation on the northern coast of the state of Bahia and appear as an alternative to the prevalent 'Pera' sweet orange on 'Rangpur' lime combination.
\end{abstract}

Index terms: Citrus spp., fruit quality, production, tree size, variety diversification.

\section{Desempenho inicial de combinações alternativas de copas e de porta-enxertos de citros no litoral norte da Bahia}

\section{Corresponding author:}

Received: July 24, 2017. Accepted: November 16, 2017.

Copyright: All the contents of this journal, except where otherwise noted, is licensed under a Creative Commons Attribution License.

\section{(cc) $\mathrm{EY}$}

Resumo - A diversificação de variedades-copa e porta-enxerto é altamente necessária à citricultura no Nordeste do Brasil. Avaliou-se o desempenho inicial de 13 variedades de laranjeira-doce enxertadas em citrandarineiro 'San Diego', além da laranjeira-de-umbigo 'Cara Cara' e da limeira-ácida 'Tahiti CNPMF-02' sobre diversos porta-enxertos, em Inhambupe, no Litoral Norte do Estado da Bahia. Três experimentos foram conduzidos separadamente, sendo o plantio realizado em 2008, no espaçamento de $6,0 \mathrm{~m}$ x 3,0 m, com irrigação suplementar. Avaliaram-se tamanho da planta, produção e qualidade dos frutos nas três safras iniciais. As laranjeiras 'Aquiri', 'Biondo', 'Agridoce', 'Kona', 'Pineapple', 'Russas CNPMF-03'e 'Salustiana' acumularam maior produção de frutos no período. As laranjeiras 'Pera CNPMF D-6', 'Westin CNPMF' e 'Salustiana' apresentaram frutos com poucas sementes, sendo apropriadas ao mercado in natura, além da maior eficiência de produção da copa da primeira. Apesar de a 'Westin CNPMF' apresentar boa qualidade de frutos, sua produção inicial foi menor. Os limoeiros 'Rugoso da Flórida' e 'Volkameriano' induziram maior produção acumulada à laranjeira 'Cara Cara'. O tamanho das árvores e a qualidade dos frutos não foram influenciados pelos porta-enxertos avaliados. A tangerineira 'Cleópatra' e o citrandarineiro 'Riverside' determinaram à limeira-ácida 'Tahiti CNPMF-02' maiores volumes de copa, produção acumulada e tamanho de frutos. Todas as combinações apresentadas acima de copa e porta-enxerto apresentam potencial para cultivo no Litoral Norte da Bahia, sendo alternativas à combinação predominante, laranjeira 'Pera' enxertada em limoeiro 'Cravo'.

Termos para indexação: Citrus spp., diversificação de variedades, produção, qualidade de frutos, tamanho de árvore.

\footnotetext{
${ }^{1}$ Agronomist, Master of Science in Agrarian Sciences, Federal University of Recôncavo da Bahia, Cruz das Almas-BA. Emails: m.s.amorim@hotmail.com, natianafranca@yahoo.com.br. Master's work of the first author with CAPES scholarship.

${ }^{2}$ Agronomist, researcher at Embrapa Cassava \& Fruits, Cruz das Almas-BA. Emails: eduardo.girardi@embrapa.br; abelmon.gesteira@embrapa.br, walter. soares@embrapa.br, orlando.passos@embrapa.br
} 


\section{Introduction}

Sweet orange [Citrus sinensis (L.) Osbeck] and 'Persian' acid lime [C. latifolia (Yu. Tanaka) Tanaka] are the main citrus fruits produced in the state of Bahia, with 962,978 and 136,064 $t$ in an cultivated area of about 62,380 and 6,361 ha, respectively (IBGE, 2015). In this state, the third citrus producer in Brazil, about $90 \%$ of the area is cultivated with the combination of 'Pera' sweet orange grafted onto 'Rangpur' lime ( $C$. limonia Osbeck), which is also the main rootstock for 'Persian' lime, and the activity is mainly family farming (ALMEIDA; PASSOS, 2011).

This predominance could be explained by the good adaptation of this combination to local edaphoclimatic conditions, characterized by constantly high air temperatures, severe drought in the summer and high air humidity in the winter, and subsurface cohesive soils (CINTRA, 2007). Cultivation is mainly rain-fed and focused on the fresh fruit domestic market with some processing (ALMEIDA; PASSOS, 2011).

On the other hand, the lack of diversification increases the risks regarding abiotic and biotic stresses either to restricted harvesting period and market opportunities. Therefore, significant efforts have been recently made in order to evaluate and recommend new citrus varieties, both scion and rootstocks, in the region (CARVALHO et al., 2015a, 2015b, 2015c, 2016; MARTINS et al., 2016; FRANÇA et al., 2016; SANTOS et al., 2016).

In this study, the initial performance of 13 sweet orange varieties grafted onto 'San Diego' citrandarin $[C$. sunki (Hayata) hort. ex Tanaka x Poncirus trifoliata (L.) Rafinesque 'Swingle'-314], and of 'Cara Cara' navel sweet orange (C. sinensis) and 'CNPMF-02 Persian' lime (C. latifolia) grafted onto several rootstocks, was assessed on the northern coast of the state of Bahia.

\section{Material and methods}

The study was conducted in the municipality of Inhambupe $\left(11^{\circ} 47^{\prime} 9^{\prime \prime} \mathrm{S}, 38^{\circ} 20^{\prime} 58^{\prime \prime} \mathrm{W}, 152 \mathrm{~m}\right.$ a. s. 1.). According to the Köppen classification, the climate of the region is a transition from Am to Aw (tropical sub humid to dry), and the soil in the experimental area was a dystrophic cohesive red yellow latosol. Climate variables throughout the harvesting period (2012-2014) are presented (Figure 1). Chemical soil attributes in 2012 at $0-10 \mathrm{~cm}$ in the tree row were: $\mathrm{pH}\left(\mathrm{CaCl}_{2}\right) 5.4, \mathrm{O} . \mathrm{M} .16$ and P $69\left(\mathrm{~g} \mathrm{dm}^{-3}\right), \mathrm{K} 1.2, \mathrm{Ca} 40, \mathrm{Mg} 3, \mathrm{H}+\mathrm{Al} 17, \mathrm{Al} 0, \mathrm{SB}$ 45 and CTC $61\left(\mathrm{mmol}_{\mathrm{c}} \mathrm{dm}^{-3}\right), \mathrm{V} 73 \%, \mathrm{~S}_{-} \mathrm{SO}_{4} 53, \mathrm{~B} 0.67$, $\mathrm{Cu}$ 1.2, Fe 33, Mn 1.2 and $\mathrm{Zn} 1.6\left(\mathrm{mg} \mathrm{dm}^{-3}\right)$.

Trees were planted in September 2008 at $6.0 \mathrm{~m} \mathrm{x}$ $3.0 \mathrm{~m}$ spacing, with subsoiling on the tree row performed at $50 \mathrm{~cm}$ depth, and other cultural practices traditionally recommended for citrus production in Northeastern Brazil were adopted (AZEVEDO, 2003). In the first two years after planting, citrus was intercropped with papaya (Carica papaya L.). Supplemental drip irrigation was used throughout the evaluation period.

Sweet orange varieties assessed were Aquiri, Biondo, Jaffa, Kona, Melrosa, Pera CNPMF D-6, Pineapple, Russas CNPMF-03, Salustiana, Seleta Amarela, Sunstar and Westin CNPMF, all grafted onto 'San Diego' citrandarin (Figure 2-A to J). 'Agridoce' is a complex sweet orange hybrid that was also evaluated in this experiment. A second trial evaluated 'Cara Cara' navel sweet orange (Figure 2-K) grafted onto 'Rangpur' lime, 'Florida' and 'Vangasay' rough lemons (C. jambhiri Lush.), 'Volkamer' lemon (C. volkameriana Ten. \& Pasq.), 'BRS Tropical Sunki' mandarin (C. sunki) and 'Indio' citrandarin (C. sunki x P. trifoliata 'English'-256).

Finally, in a third experiment, 'CNPMF-02 Persian lime' (Figure 2-L) was grafted onto CRC 1452, 70-133, 4570-A and 'Swingle' (4475) citrumelos (C. paradisi Macfaden x P. trifoliata), 'Stanford' citrange (C. sinensis x P. trifoliata), P. trifoliata, 'Cleopatra' mandarin $(C$. reshni hort. ex Tanaka), and citrandarins 'Riverside' ( $C$. sunki $\mathrm{x}$ P. trifoliata 'English'-264) and 'San Diego'.

Screened nursery tress budded onto nucellar rootstocks were transplanted with $\approx 12$ months of age for all the described combinations. All plant materials were obtained from the Citrus Active Germplasm Bank and selected by the Citrus Breeding Program of Embrapa Cassava \& Fruits at Cruz das Almas, BA (PASSOS et al., 2007).

Fruit production per tree was weighted from 2012 to 2014, corresponding to the first three crops. In 2013 and 2014 (only latter data are presented), tree height $(\mathrm{H})$ and diameter (D) were measured and canopy volume $(\mathrm{V})$ was calculated by $\mathrm{V}=2 / 3 \times[(\pi \mathrm{x}$ $\left.\left.\mathrm{D}^{2} \times 4^{-1}\right) \times \mathrm{H}\right]$ (CANTUARIAS-AVILÉS et al., 2012). Production efficiency obtained from the ratio between tree production and canopy volume was estimated as an average of 2013 and 2014.

Fruit quality variables included: weight (g), width and height $(\mathrm{cm})$, number of seeds per fruit, juice yield $(\mathrm{Y})$ (\%), total soluble solids (SS) $\left({ }^{\circ}\right.$ Brix), titratable acidity (TA) ( $\mathrm{g}$ of citric acid $\mathrm{mL}^{-1}$ ), maturity index (SS/TA), and technological index (TI) $\left(\mathrm{kg} \mathrm{SS}\right.$ box $\left.{ }^{-1}\right)$, calculated by: TI $=[\mathrm{Y} \times \mathrm{SS} \times 40.8] \times 10,000^{-1}$, where $40.8 \mathrm{~kg}$ corresponds to the standard box (CARVALHO et al., 2015a). For analyses, ten fruits per plot were collected when they visually reached ripeness. Sweet oranges were harvested in July 2012, 2013 and 2014; 'Persian' lime was sampled in July 2013 and 2014; and 'Cara Cara' navel sweet orange was analyzed only in February 2014.

The experimental design was randomized blocks with four replicates and two trees in the plot, and the three trials were analyzed separately. Results were submitted 
to analysis of variance and averages were grouped by the Scott-Knott test $(P<0.05)$, transforming them through the formula $(\mathrm{X}+0.5)^{\wedge} 0.5$, whenever necessary in order to reach normality and homogeneity of variance.

\section{Results and discussion}

\section{Evaluation of 13 sweet orange varieties grafted onto 'San Diego' citrandarin}

In 2012, Aquiri, Biondo, Agridoce, Jaffa, Kona, Pineapple, Russas CNPMF-03 and Sunstar varieties were the most productive (Table 1). In 2013, 'Agridoce' and 'Pera CNPMF D-6' showed the highest productions, while in 2014, 'Aquiri', 'Kona', 'Pineapple', and 'Salustiana' were the most productive. With respect to the cumulative production in the first three crops, Aquiri, Biondo, Agridoce, Kona, Pineapple, Russas CNPMF-03 and Salustiana cultivars stood out.

Production was assessed from 2012 to 2014, performing two harvests per year in 2012 (June and October) and in 2013 (February and August) and four harvests in 2014 (January, March, June and October). All evaluated varieties presented multiple blooms throughout the year, with fruit production varying according to the climatic conditions within each year (Figure 1); thus, no varietal pattern regarding out season production could be clearly identified during the evaluation period.

The variety with the largest tree size was 'Agridoce', probably a hybrid between sweet orange and sour orange (C. aurantium L.), which showed the highest tree height, diameter and canopy volume, followed by 'Russas CNPMF-03' and 'Salustiana' (Table 1). 'Melrosa', 'Pera CNPMF D-6' and 'Seleta Amarela'; on the other hand, showed the lowest canopy volume. As a result, 'Aquiri', 'Biondo', 'Jaffa', 'Kona', 'Melrosa', 'Pera CNPMF D-6', 'Pineapple' and 'Seleta Amarela' varieties showed the highest average production efficiency in 2013 and in 2014 (Table 1).

'Agridoce' variety had larger and heavier fruits, thicker fruit peel, lower juice yield and lower acidity, and lower technological index (TI) (Table 2), significantly differing from sweet oranges evaluated. Fruit weight and dimensions were similar among varieties, except for higher means for 'Melrosa' variety. The highest maturity index (SS/TA) was also found in 'Agridoce' fruits, which showed the earliest maturation, followed by 'Melrosa' (Table 2). Aquiri, Biondo, Jaffa, Pera CNPMF D-6, Russas CNPMF-03, Seleta Amarela and Sunstar were the latest season varieties.

'Aquiri', 'Pera CNPMF-D6', 'Salustiana' and 'Westin CNPMF' had the highest juice content, $\approx 49 \%$, with other cultivars showing yields below the desired industrial standard (Table 2). 'Aquiri', 'Biondo', 'Jaffa', 'Kona', 'Russas CNPMF-03', 'Pineapple' and 'Seleta
Amarela' varieties showed higher number of seeds per fruit, with average equal to or higher than 16 , while 'Pera CNPMF-D6', 'Salustiana' and 'Westin CNPMF' varieties presented the lowest number, $\approx 4$, and may be considered as seedless, which makes them more suitable for fresh consumption.

With respect to soluble solids (SS) in the juice, 'Biondo', 'Jaffa', 'Kona', 'Salustiana', 'Seleta Amarela' and 'Westin CNPMF' varieties presented the highest content $\approx 11.5^{\circ}$ Brix (Table 2). The smallest TI $(<2.0 \mathrm{~kg}$ $\mathrm{SS}$ box $^{-1}$ ) was obtained in 'Agridoce', 'Russas CNPMF-03' and 'Sunstar' fruits (Table 2), corroborating their low suitability for juice processing standards (POZZAN; TRIBONI, 2005).

There is scarce information on the majority of the evaluated sweet oranges. 'Kona' sweet orange was early season and presented higher tree vigor and production efficiency than 'Pera CNPMF-D6' in Umbaúba, State of Sergipe, Brazil (MARTINS et al., 2016). 'Russas CNPMF-03' variety stood out for its fruit quality among local selections of sweet orange in Russas, State of Ceará, Brazil (PASSOS et al., 2013). 'Melrosa' was identified as a potential variety for the State of Piauí, Brazil (PASSOS et al., 2007).

'Aquiri' sweet orange had greater canopy volume when grafted onto 'Rangpur' lime, 'Cleopatra' mandarin and 'Carrizo' citrange in the State of Acre, where it was selected (LEDO et al., 1999). In the present study, 'Aquiri' sweet orange also showed good production and vigor when grafted onto 'San Diego' citrandarin. Characteristics such as absence of seeds, high fruit quality and high tree vigor of 'Salustiana' sweet orange have been reported by Castle and Baldwin (2011) in Florida, USA, although the authors observed lower production on 'Swingle' citrumelo rootstock. 'Pineapple' was highlighted for its high production in the State of Sergipe (Carvalho et al., 2015b). Medeiros et al. (2013), assessing the qualitative characteristics of 15 sweet orange varieties in the State of Pernambuco, Brazil, classified Pineapple, Salustiana, and Sunstar cultivars as maturation in mid-season. These results are in accordance with the maturity order observed in the present study, in relation to the maturity index (Table 2). In general, the juice quality results reported herein indicate SS content and industrial yield compatible with young orchards and oranges produced in tropical climate.

Considering the overall performance in the first three seasons, 'Pera CNPMF D-6', 'Westin CNPMF' and 'Salustiana' sweet oranges showed greater potential for cultivation on the Northern Coast of Bahia due to the high fruit quality and low number of seeds, in addition to the greater production efficiency of 'Pera CNPMF D-6' and highest cumulative production of 'Salustiana' variety. The presence of many seeds in the fruits of other assessed varieties, despite their high initial production and high juice quality, makes them inadequate for the fresh fruit 
market. Both 'Pera CNPMF D-6' and 'Westin CNPMF' varieties are nucellar clones obtained in Cruz das Almas (PASSOS et al., 2007).

Until the seventh year of age, any symptoms related to graft incompatibility, blight and Phytophthora spp. gummosis were observed, despite the well-known graft incompatibility between 'Pera' sweet orange and the majority of trifoliate orange hybrids (POMPEU JUNIOR, 2005). However, the behavior of all grafted varieties on 'San Diego' citrandarin should be evaluated for a longer period in order to conclude about their performance and fruit quality along the orchard lifespan.

\section{Evaluation of 'Cara Cara' navel sweet orange grafted onto six rootstocks}

Fruit production was measured from 2012 to 2014 (three initial seasons), with two harvests in 2012 (June and October), two harvests in 2013 (February and June), and four harvests in 2014 (January, March, June and October). 'Florida' rough lemon and 'Volkamer' lemon induced the highest cumulative production to 'Cara Cara' sweet orange in this period, and 'Volkamer' lemon was slightly earlier bearing rootstock (Table 3). Tree size and production efficiency were similar regardless of rootstock, on average $24 \mathrm{~m}^{3}$ of canopy volume and $5 \mathrm{~kg}$ $\mathrm{m}^{-3}$, respectively.

'Cara Cara' is considered a bud sport mutant of navel sweet orange from Venezuela, with increasing interest in recent years due to its lycopene accumulation in the red pulp (ALQUEZAR et al., 2008). It is well adapted to tropical arid climate, giving high quality fruits but usually with low production (URRUTIA et al., 2007). However, there are few studies on the performance on different rootstocks (OLIVEIRA et al., 2013).

In three regions of Porto Rico, 'Cara Cara' sweet orange was more productive and presented higher survival to Phytophthora spp. gummosis when grafted onto 'Swingle' citrumelo in relation to 'Cleopatra' mandarin (PÉREZ et al., 2006). The authors also reported that 'Carrizo' citrange (C. sinensis $\mathrm{x} P$. trifoliata) induced 'Cara Cara' fruits with higher SS content than those on 'Swingle' citrumelo, while the maturity index was higher for 'Cleopatra' mandarin in relation to 'Swingle' citrumelo and 'Sun Chu Sha' mandarin (C. reticulata Blanco), but similar to 'Carrizo' citrange.

Wright (2007) studied several navel oranges grafted onto 'Carrizo' citrange, including 'Cara Cara', in the arid climate of Arizona, USA. This combination resulted in high cumulative production, larger fruits and higher SS content in most of the evaluated seasons. It was concluded that 'Cara Cara' was an interesting alternative to traditional 'Washington Navel' in that region, among other varieties.

Although 'Florida' rough lemon induced higher initial production to 'Cara Cara' sweet orange (Table
3), Soares Filho et al. (1981) had previously evaluated rootstocks for the original 'Bahia' or 'Washington Navel' sweet orange in the Recôncavo da Bahia region and observed high incidence of Phytophthora spp. gummosis on 'Florida' rough lemon, which may limit its commercial use on the Coastal Tablelands.

Fruit diameter was the only physicochemical trait of 'Cara Cara' fruits that was influenced by rootstock, with 'Volkamer' lemon and 'Vangasay' rough lemon leading to wider fruits with $\approx 8.7 \mathrm{~cm}$ (Table 4). In the evaluated conditions, 'Cara Cara' sweet orange fruits presented, on average, $314 \mathrm{~g}, 8.1 \mathrm{~cm} \times 8.4 \mathrm{~cm}$, peel thickness of $6.21 \mathrm{~mm}, 36 \%$ of juice yield, no seeds at all, TA of $0.55 \%, 9.78{ }^{\circ}$ Brix, maturity index (SS/TA) of 17.7 and TI of $1.44 \mathrm{~kg} \mathrm{SS} \mathrm{box}^{-1}$. These characteristics are typical of early season navel sweet oranges, and along with the distinct lycopene-rich deep red pulp, make this variety a major alternative for commercial cultivation in northeastern Brazil.

\section{Evaluation of 'CNPMF-02 Persian' lime grafted onto nine rootstocks}

In 2012, 70-133 citrumelo, 'Riverside' and 'San Diego' citrandarins induced higher production of 'CNPMF-02 Persian' lime (Table 5). In 2013, there was no difference among evaluated rootstocks, and in 2014 'Cleopatra' mandarin and 'Riverside' citrandarin stood out. The latter two rootstocks led to the highest cumulative production up to seven years of age. There were two harvests in 2012 (July and October), and four in 2013 and 2014, both in March, July, October and December. Trees were not managed to induce out season flowering, which was naturally spontaneous after drought periods (Figure 1).

'Cleopatra' mandarin, 'Swingle' citrumelo (4475) and 'Riverside' and 'San Diego' citrandarins led to taller but narrower canopies (Table 5). 4570-A citrumelo and trifoliate orange induced the lowest canopy volume. Nevertheless, production efficiency was similar regardless of rootstock; with average of $2.34 \mathrm{~kg} \mathrm{~m}^{-3}$.

All fruit quality variables were also not influenced by rootstocks, except for fruit weight (Table 6). CRC 1452 citrumelo, 'Cleopatra' mandarin, 'Riverside' and 'San Diego' citrandarins resulted in heavier 'CNPMF-02 Persian' lime fruits, on average $140 \mathrm{~g}$, while the other resulted in $\approx 124 \mathrm{~g}$ per fruit. Mean values for fruit traits were: $6.52 \mathrm{~cm} \times 5.95 \mathrm{~cm}$, peel thickness of $3.52 \mathrm{~mm}$, $36.5 \%$ of juice yield, $6.22 \%$ of acidity, $9.62{ }^{\circ}$ Brix, maturity index of 1.58 and TI of $1.49 \mathrm{~kg} \mathrm{SS} \mathrm{box}^{-1}$. No seeds were recorded.

'CNPMF-01' and 'CNPMF-02' are nucellar selections of 'Persian' lime, widely cultivated in Northeastern Brazil, and presented good performance on 'Swingle' citrumelo in relation to the standard clone, 'IAC-5', in the 'Recôncavo da Bahia' region, state 
of Bahia (SANTOS et al., 2016). Therefore, results presented here corroborate its commercial use.

Although several differences are reported on 'Persian' lime tree size due to rootstocks, only 'Flying Dragon' trifoliate ( $P$. trifoliata var. monstrosa) has been classified as truly dwarfing rootstock for this scion species so far (STENZEL; NEVES, 2004; CANTUARIASAVILÉS et al., 2012; BREMER NETO et al., 2013). As a result, production efficiency of 'Persian' lime was generally lower in comparison to the evaluated sweet oranges because the former presented larger trees (Tables 1, 3 and 5).

Regarding the physicochemical fruit quality of 'Persian' lime, in general, rootstocks have minor effects (STENZEL; NEVES, 2004; STUCHI et al., 2009). Stenzel and Neves (2004) observed fruit weight ranging from 96 to $113 \mathrm{~g}$, while Stuchi et al. (2009) found 81 to $96 \mathrm{~g}$ on eleven rootstocks. The present work reports higher fruit weights, from 117 to $145 \mathrm{~g}$, which may be related to the climate conditions.

For exports, peel thickness is also an important trait (GAYET; SALVO FILHO, 2003). 'Swingle' citrumelo, 'Rangpur' lime and 'Flying Dragon' trifoliate resulted in thinner fruit peel of 'Persian' lime (STUCHI et al., 2009) and, although it was not significant in this work, the mean value was the lowest for the former rootstock (Table 6).

Taking together the results from the three experiments, fruit yield was clearly high in comparison to the average productivity of sweet oranges in the state of Bahia (15.43 t ha-1) and acid limes $\left(21.39 \mathrm{t} \mathrm{ha}^{-1}\right)$ in 2015 (IBGE, 2015). The most productive sweet orange varieties yielded, on average, $54.63 \mathrm{t} \mathrm{ha}^{-1}$, with the most efficient yielding $8 \mathrm{~kg} \mathrm{~m}^{-3}$ (Table 1). 'Cara Cara' navel sweet orange and 'CNPMF-02 Persian' lime had mean yield of 42.54 and $38.18 \mathrm{t} \mathrm{ha}^{-1}$, respectively, when grafted onto the most productive rootstocks. Therefore, it could be inferred that the combinations under study may be useful to the diversification of citrus cultivars in Northeastern Brazil, an old long lasting task (ALMEIDA; PASSOS, 2011). The performance of these varieties must be evaluated in the long term to consolidate these results, and economical studies regarding the suitability of offseason production and specific traits such as seedlessness for higher prices in the fresh fruit market should be considered for the decision making of growers.

Despite the fact that none of the evaluated rootstocks were dwarfing, overall tree performance was good up to seven years after planting at $6 \mathrm{~m} \mathrm{x} 3$ $\mathrm{m}$, which gives tree density of 555 trees $\mathrm{ha}^{-1}$. Usually, tree density recommended for Northeastern Brazil is 416 trees ha $^{-1}$ (6 m x $4 \mathrm{~m}$ ) (AZEVEDO, 2003). The use of supplemental irrigation in all plots also corroborated the above mentioned high yields, as previously reported for 'Persian' lime grafted onto different rootstocks
(ESPINOZA-NUÑEZ et al., 2011; BREMER NETO et al., 2013). This observation reinforces the argument that citrus cultivation on the Northeastern Coastal Tablelands strongly benefits from irrigation as it is usually dry farming subjected to frequent drought events (COELHO et al., 2006). On the other hand, the irrigation management used in this study did not prevent the occurrence of multiple flowerings within the evaluated varieties and rootstocks. This behavior has resulted in several harvests throughout the year, which in turn allows for continuous cash flow to the grower, even though phytossanitary costs are expected to increase.

Finally, it is worth highlighting the general good performance of the evaluated rootstocks as alternative to 'Rangpur' lime in the state of Bahia. 'Volkamer' lemon, 'Cleopatra' mandarin and 'Florida' rough lemon were confirmed as suitable rootstocks in the region, as previously observed in rain-fed cultivation of 'Pera CNPMF D-6' sweet orange in the state of Sergipe under similar edaphoclimatic conditions (PRUDENTE et al., 2004). New rootstock varieties such as the evaluated citrandarins and 'Sunki Tropical' mandarin also resulted in high production and tree survival rates in several studies recently carried out in the region and, thus, constitute promising rootstocks (CARVALHO et al., 2015a, 2015b, 2015c, 2016; FRANÇA et al., 2016). 
Table 1. Annual and cumulative fruit production (P) from 2012 to 2014 (three initial crops), height (H), diameter (D), volume (V) in 2014, and mean production efficiency (P/V) in 2013-2014 of 13 sweet orange varieties grafted onto 'San Diego' citrandarin on the northern coast of the state of Bahia, Brazil.

\begin{tabular}{lcccccccc}
\hline Varieties' & P 2012 & P 2013 & P 2014 & P 2012-2014 & $\mathrm{H}$ & $\mathrm{D}$ & $\begin{array}{c}\mathrm{V} \\
\left(\mathrm{m}^{3}\right)\end{array}$ & $\begin{array}{c}\text { P/V } \\
\left(\mathrm{kg} \mathrm{m}^{-3}\right)\end{array}$ \\
\hline 'Aquiri' & $60.8 \mathrm{a}$ & $78.5 \mathrm{~b}$ & $156.0 \mathrm{a}$ & $295.3 \mathrm{a}$ & $2.7 \mathrm{~d}$ & $3.8 \mathrm{c}$ & $21.7 \mathrm{c}$ & $8.2 \mathrm{a}$ \\
'Biondo' & $56.5 \mathrm{a}$ & $86.4 \mathrm{~b}$ & $141.9 \mathrm{~b}$ & $284.9 \mathrm{a}$ & $3.0 \mathrm{c}$ & $3.9 \mathrm{c}$ & $24.6 \mathrm{c}$ & $7.9 \mathrm{a}$ \\
'Agridoce' & $76.3 \mathrm{a}$ & $124.5 \mathrm{a}$ & $107.8 \mathrm{~b}$ & $308.7 \mathrm{a}$ & $3.6 \mathrm{a}$ & $4.4 \mathrm{a}$ & $37.7 \mathrm{a}$ & $5.4 \mathrm{~b}$ \\
'Jaffa' & $53.0 \mathrm{a}$ & $73.8 \mathrm{~b}$ & $121.0 \mathrm{~b}$ & $247.9 \mathrm{~b}$ & $2.8 \mathrm{~d}$ & $3.7 \mathrm{c}$ & $21.1 \mathrm{c}$ & $7.3 \mathrm{a}$ \\
'Kona' & $65.0 \mathrm{a}$ & $79.6 \mathrm{~b}$ & $154.2 \mathrm{a}$ & $298.9 \mathrm{a}$ & $3.0 \mathrm{c}$ & $3.7 \mathrm{c}$ & $23.5 \mathrm{c}$ & $7.4 \mathrm{a}$ \\
'Melrosa' & $21.5 \mathrm{~b}$ & $79.6 \mathrm{~b}$ & $79.6 \mathrm{~b}$ & $180.7 \mathrm{~b}$ & $2.6 \mathrm{~d}$ & $3.3 \mathrm{~d}$ & $15.6 \mathrm{~d}$ & $9.0 \mathrm{a}$ \\
'Pera CNPMF D-6' & $39.4 \mathrm{~b}$ & $106.2 \mathrm{a}$ & $111.4 \mathrm{~b}$ & $257.1 \mathrm{~b}$ & $2.6 \mathrm{~d}$ & $3.6 \mathrm{c}$ & $18.7 \mathrm{~d}$ & $8.6 \mathrm{a}$ \\
'Pineapple' & $60.5 \mathrm{a}$ & $74.3 \mathrm{~b}$ & $146.7 \mathrm{a}$ & $281.6 \mathrm{a}$ & $3.2 \mathrm{~b}$ & $3.7 \mathrm{c}$ & $24.4 \mathrm{c}$ & $7.4 \mathrm{a}$ \\
'Russas CNPMF-03' & $63.7 \mathrm{a}$ & $90.2 \mathrm{~b}$ & $176.1 \mathrm{a}$ & $330.0 \mathrm{a}$ & $3.4 \mathrm{~b}$ & $4.1 \mathrm{~b}$ & $29.9 \mathrm{~b}$ & $6.7 \mathrm{~b}$ \\
'Salustiana' & $35.1 \mathrm{~b}$ & $84.1 \mathrm{~b}$ & $146.7 \mathrm{a}$ & $265.9 \mathrm{a}$ & $3.6 \mathrm{a}$ & $4.1 \mathrm{~b}$ & $32.2 \mathrm{~b}$ & $5.8 \mathrm{~b}$ \\
'Seleta Amarela' & $47.4 \mathrm{~b}$ & $71.7 \mathrm{~b}$ & $119.1 \mathrm{~b}$ & $238.3 \mathrm{~b}$ & $2.6 \mathrm{~d}$ & $3.3 \mathrm{~d}$ & $15.4 \mathrm{~d}$ & $8.9 \mathrm{a}$ \\
'Sunstar' & $52.1 \mathrm{a}$ & $65.3 \mathrm{~b}$ & $126.3 \mathrm{~b}$ & $243.8 \mathrm{~b}$ & $3.0 \mathrm{c}$ & $3.8 \mathrm{c}$ & $23.4 \mathrm{c}$ & $6.8 \mathrm{~b}$ \\
'Westin CNPMF' & $28.4 \mathrm{~b}$ & $67.4 \mathrm{~b}$ & $90.4 \mathrm{~b}$ & $186.3 \mathrm{~b}$ & $3.3 \mathrm{~b}$ & $3.7 \mathrm{c}$ & $24.3 \mathrm{c}$ & $5.5 \mathrm{~b}$ \\
\hline CV (\%) & 15.9 & 26.9 & 29.6 & 18.6 & 7.0 & 5.3 & 12.1 & 21.3 \\
\hline
\end{tabular}

(*)Averages followed by different letters in column belong to distinct groups by the Scott-Knott test $(\mathrm{P}<0.05)$.

${ }^{1}$ Scientific names of the species and varieties are described in Material and Methods.

Table 2. Weight (W), length (L), diameter (D), peel thickness (P), juice yield (Y), number of seeds $(\mathrm{N})$, titratable acidity (TA), soluble solids (SS), maturity index (SS/TA) and technological index (TI) of fruits of 13 sweet orange varieties grafted onto 'San Diego' citrandarin on the northern coast of the state of Bahia, Brazil, in the period 2012-2014.

\begin{tabular}{lcccccccccc}
\hline Varieties' & $\begin{array}{c}\mathrm{W} \\
(\mathrm{g})\end{array}$ & $\begin{array}{c}\mathrm{L} \\
----(\mathrm{cm})\end{array}$ & $\begin{array}{c}\mathrm{D} \\
\text {--- }\end{array}$ & $\begin{array}{c}\mathrm{P} \\
(\mathrm{mm})\end{array}$ & $\begin{array}{c}\mathrm{Y} \\
(\%)\end{array}$ & $\begin{array}{c}\mathrm{N} \\
(\mathrm{unit})\end{array}$ & $\begin{array}{c}\text { TA } \\
(\%)\end{array}$ & $\begin{array}{c}\text { SS } \\
\left({ }^{\circ} \mathrm{Brix}\right)\end{array}$ & $\mathrm{SS} / \mathrm{TA}$ & $\mathrm{TI}^{2}$ \\
\hline 'Aquiri' & $211 \mathrm{c}$ & $7.0 \mathrm{~b}$ & $7.5 \mathrm{c}$ & $4.0 \mathrm{c}$ & $47 \mathrm{a}$ & $20 \mathrm{a}$ & $1.13 \mathrm{a}$ & $10.9 \mathrm{~b}$ & $9.9 \mathrm{~d}$ & $2.13 \mathrm{a}$ \\
'Biondo' & $200 \mathrm{c}$ & $7.0 \mathrm{~b}$ & $7.3 \mathrm{c}$ & $4.2 \mathrm{c}$ & $45 \mathrm{~b}$ & $19 \mathrm{a}$ & $1.29 \mathrm{a}$ & $11.5 \mathrm{a}$ & $9.2 \mathrm{~d}$ & $2.16 \mathrm{a}$ \\
'Agridoce' & $298 \mathrm{a}$ & $8.0 \mathrm{a}$ & $8.9 \mathrm{a}$ & $8.1 \mathrm{a}$ & $37 \mathrm{c}$ & $8 \mathrm{~d}$ & $0.31 \mathrm{c}$ & $10.7 \mathrm{~b}$ & $35.3 \mathrm{a}$ & $1.64 \mathrm{c}$ \\
'Jaffa' & $212 \mathrm{c}$ & $7.0 \mathrm{~b}$ & $7.4 \mathrm{c}$ & $4.2 \mathrm{c}$ & $44 \mathrm{~b}$ & $19 \mathrm{a}$ & $1.24 \mathrm{a}$ & $11.5 \mathrm{a}$ & $9.5 \mathrm{~d}$ & $2.08 \mathrm{a}$ \\
'Kona' & $210 \mathrm{c}$ & $7.2 \mathrm{~b}$ & $7.3 \mathrm{c}$ & $4.1 \mathrm{c}$ & $44 \mathrm{~b}$ & $16 \mathrm{~b}$ & $0.88 \mathrm{~b}$ & $11.3 \mathrm{a}$ & $13.7 \mathrm{c}$ & $2.06 \mathrm{a}$ \\
'Melrosa' & $266 \mathrm{~b}$ & $7.7 \mathrm{a}$ & $8.3 \mathrm{~b}$ & $5.6 \mathrm{~b}$ & $45 \mathrm{~b}$ & $11 \mathrm{c}$ & $0.75 \mathrm{~b}$ & $11.7 \mathrm{a}$ & $16.7 \mathrm{~b}$ & $2.19 \mathrm{a}$ \\
'Pera CNPMF D-6' & $208 \mathrm{c}$ & $7.1 \mathrm{~b}$ & $7.2 \mathrm{c}$ & $3.5 \mathrm{c}$ & $51 \mathrm{a}$ & $5 \mathrm{e}$ & $0.99 \mathrm{~b}$ & $10.9 \mathrm{~b}$ & $11.3 \mathrm{~d}$ & $2.32 \mathrm{a}$ \\
'Pineapple' & $224 \mathrm{c}$ & $7.2 \mathrm{~b}$ & $7.5 \mathrm{c}$ & $3.9 \mathrm{c}$ & $46 \mathrm{~b}$ & $16 \mathrm{~b}$ & $0.90 \mathrm{~b}$ & $11.0 \mathrm{~b}$ & $13.1 \mathrm{c}$ & $2.12 \mathrm{a}$ \\
'Russas CNPMF-03' & $204 \mathrm{c}$ & $7.1 \mathrm{~b}$ & $7.3 \mathrm{c}$ & $4.3 \mathrm{c}$ & $45 \mathrm{~b}$ & $16 \mathrm{~b}$ & $0.96 \mathrm{~b}$ & $10.5 \mathrm{~b}$ & $11.8 \mathrm{~d}$ & $1.94 \mathrm{~b}$ \\
'Salustiana' & $179 \mathrm{c}$ & $7.1 \mathrm{~b}$ & $7.1 \mathrm{c}$ & $4.3 \mathrm{c}$ & $50 \mathrm{a}$ & $2 \mathrm{f}$ & $0.87 \mathrm{~b}$ & $11.2 \mathrm{a}$ & $13.6 \mathrm{c}$ & $2.31 \mathrm{a}$ \\
'Seleta Amarela' & $215 \mathrm{c}$ & $7.1 \mathrm{~b}$ & $7.4 \mathrm{c}$ & $4.3 \mathrm{c}$ & $46 \mathrm{~b}$ & $18 \mathrm{a}$ & $1.03 \mathrm{~b}$ & $10.9 \mathrm{~b}$ & $10.1 \mathrm{~d}$ & $2.09 \mathrm{a}$ \\
'Sunstar' & $185 \mathrm{c}$ & $6.9 \mathrm{~b}$ & $7.1 \mathrm{c}$ & $4.6 \mathrm{c}$ & $45 \mathrm{~b}$ & $11 \mathrm{c}$ & $1.14 \mathrm{a}$ & $10.6 \mathrm{~b}$ & $9.9 \mathrm{~d}$ & $1.99 \mathrm{~b}$ \\
'Westin CNPMF' & $194 \mathrm{c}$ & $6.8 \mathrm{~b}$ & $7.1 \mathrm{c}$ & $4.3 \mathrm{c}$ & $48 \mathrm{a}$ & $6 \mathrm{e}$ & $0.96 \mathrm{~b}$ & $11.8 \mathrm{a}$ & $13.2 \mathrm{c}$ & $2.33 \mathrm{a}$ \\
\hline CV (\%) & 9.0 & 3.1 & 3.1 & 10.4 & 6.8 & 14.3 & 12.6 & 4.1 & 10.6 & 8.7 \\
\hline
\end{tabular}

$\left.{ }^{*}\right)$ Averages followed by different letters in column belong to distinct groups by the Scott-Knott test $(\mathrm{P}<0.05) .{ }^{1}$ Scientific names of the species and varieties are described in Material and Methods. ${ }^{2} \mathrm{~kg} \mathrm{SS}$ box $^{-1} 40.8 \mathrm{~kg}$ 
Table 3. Annual and cumulative fruit production (P) from 2012 to 2014 (three initial crops), height (H), diameter (D), volume (V) in 2014, and mean production efficiency (P/V) in 2013-2014 of 'Cara Cara' navel sweet orange grafted onto six rootstocks on the northern coast of the state of Bahia, Brazil.

\begin{tabular}{|c|c|c|c|c|c|c|c|c|}
\hline \multirow{2}{*}{ Rootstocks $^{1}$} & P 2012 & P 2013 & P 2014 & P 2012-2014 & $\mathrm{H}$ & $\mathrm{D}$ & \multirow{2}{*}{$\begin{array}{c}\mathrm{V} \\
\left(\mathrm{m}^{3}\right)\end{array}$} & \multirow{2}{*}{$\begin{array}{c}\mathrm{P} / \mathrm{V} \\
\left(\mathrm{kg} \mathrm{m}^{-3}\right)\end{array}$} \\
\hline & \multicolumn{4}{|c|}{ - } & \multicolumn{2}{|c|}{----- $(\mathrm{m})$----- } & & \\
\hline 'Rangpur' lime & $29.9 \mathrm{~b}$ & $83.9 \mathrm{a}$ & $69.6 \mathrm{a}$ & $183.4 \mathrm{~b}$ & $4.0 \mathrm{a}$ & $3.6 \mathrm{a}$ & $27.7 \mathrm{a}$ & $4.6 \mathrm{a}$ \\
\hline 'Florida' rough lemon & $32.2 \mathrm{~b}$ & $98.7 \mathrm{a}$ & $83.5 \mathrm{a}$ & $214.5 \mathrm{a}$ & $3.9 \mathrm{a}$ & $3.1 \mathrm{a}$ & $20.8 \mathrm{a}$ & $5.4 \mathrm{a}$ \\
\hline 'Volkamer' lemon & $54.5 \mathrm{a}$ & $108.6 \mathrm{a}$ & $81.8 \mathrm{a}$ & $245.0 \mathrm{a}$ & $4.0 \mathrm{a}$ & $3.0 \mathrm{a}$ & $20.4 \mathrm{a}$ & $6.5 \mathrm{a}$ \\
\hline 'BRS Tropical Sunki' mandarin & $19.3 \mathrm{~b}$ & $73.18 \mathrm{a}$ & $67.3 \mathrm{a}$ & $159.8 \mathrm{~b}$ & $3.8 \mathrm{a}$ & $3.0 \mathrm{a}$ & $19.8 \mathrm{a}$ & $5.0 \mathrm{a}$ \\
\hline 'Indio' citrandarin & $22.3 \mathrm{~b}$ & $75.09 \mathrm{a}$ & $63.1 \mathrm{a}$ & $160.6 \mathrm{~b}$ & $3.9 \mathrm{a}$ & $3.7 \mathrm{a}$ & $28.9 \mathrm{a}$ & $4.1 \mathrm{a}$ \\
\hline 'Vangasay' rough lemon & $21.3 \mathrm{~b}$ & $86.40 \mathrm{a}$ & $70.1 \mathrm{a}$ & $177.8 \mathrm{~b}$ & $4.0 \mathrm{a}$ & $3.4 \mathrm{a}$ & $26.0 \mathrm{a}$ & $4.4 \mathrm{a}$ \\
\hline CV $(\%)$ & 17.1 & 18.6 & 27.2 & 16.4 & 4.6 & 11.9 & 25.1 & 21.0 \\
\hline
\end{tabular}

$\left.{ }^{*}\right)$ Averages followed by different letters in column belong to distinct groups by the Scott-Knott test $(\mathrm{P}<0.05) .{ }^{1}$ Scientific names of the species and varieties are described in Material and Methods.

Table 4. Weight (W), length (L), diameter (D), peel thickness (P), juice yield (Y), number of seeds (N), titratable acidity (TA), soluble solids (SS), maturity index (SS/TA) and technological index (TI) of fruits of 'Cara Cara' navel sweet orange grafted onto six rootstocks on the northern coast of the state of Bahia, Brazil, in 2014.

\begin{tabular}{|c|c|c|c|c|c|c|c|c|c|c|}
\hline Rootstocks $^{1}$ & $\begin{array}{l}\text { W } \\
(\mathrm{g})\end{array}$ & $\begin{array}{l}\mathrm{L} \\
----(\mathrm{cm})\end{array}$ & D & $\begin{array}{c}\mathrm{P} \\
(\mathrm{mm})\end{array}$ & $\begin{array}{c}\mathrm{Y} \\
(\%)\end{array}$ & $\begin{array}{c}\mathrm{N} \\
\text { (unit) }\end{array}$ & $\begin{array}{l}\text { TA } \\
(\%)\end{array}$ & $\begin{array}{c}\mathrm{SS} \\
\left({ }^{\circ} \mathrm{Brix}\right)\end{array}$ & $\mathrm{SS} / \mathrm{TA}$ & $\mathrm{TI}^{2}$ \\
\hline 'Rangpur' lime & $322 \mathrm{a}$ & $8.0 \mathrm{a}$ & $8.3 \mathrm{~b}$ & $6.9 \mathrm{a}$ & $34 \mathrm{a}$ & 0 & $0.54 \mathrm{a}$ & $9.8 \mathrm{a}$ & $18.3 \mathrm{a}$ & $1.39 \mathrm{a}$ \\
\hline 'Florida' rough lemon & $283 \mathrm{a}$ & $7.6 \mathrm{a}$ & $8.0 \mathrm{~b}$ & $5.8 \mathrm{a}$ & 36 a & 0 & $0.63 \mathrm{a}$ & $9.4 \mathrm{a}$ & $15.3 \mathrm{a}$ & $1.42 \mathrm{a}$ \\
\hline 'Volkamer' lemon & $326 \mathrm{a}$ & $8.4 \mathrm{a}$ & $8.8 \mathrm{a}$ & $8.0 \mathrm{a}$ & 33 a & 0 & $0.51 \mathrm{a}$ & $9.9 \mathrm{a}$ & $17.6 \mathrm{a}$ & $1.23 \mathrm{a}$ \\
\hline 'BRS Tropical Sunki' mandarin & $305 \mathrm{a}$ & $8.1 \mathrm{a}$ & $8.3 \mathrm{~b}$ & $5.5 \mathrm{a}$ & 39 a & 0 & $0.56 \mathrm{a}$ & $9.5 \mathrm{a}$ & $17.0 \mathrm{a}$ & $1.46 \mathrm{a}$ \\
\hline 'Indio' citrandarin & $274 \mathrm{a}$ & $7.7 \mathrm{a}$ & $8.2 \mathrm{~b}$ & $5.0 \mathrm{a}$ & $43 \mathrm{a}$ & 0 & $0.52 \mathrm{a}$ & $10.2 \mathrm{a}$ & $19.8 \mathrm{a}$ & $1.81 \mathrm{a}$ \\
\hline 'Vangasay' rough lemon & $372 \mathrm{a}$ & $8.6 \mathrm{a}$ & $8.6 \mathrm{a}$ & $6.1 \mathrm{a}$ & $33 \mathrm{a}$ & 0 & $0.54 \mathrm{a}$ & $9.9 \mathrm{a}$ & $18.4 \mathrm{a}$ & $1.36 \mathrm{a}$ \\
\hline CV (\%) & 11.6 & 4.8 & 3.5 & 20.9 & 16.0 & 0 & 12.2 & 8.3 & 10.3 & 20.1 \\
\hline
\end{tabular}

$\left({ }^{*}\right)$ Averages followed by different letters in column belong to distinct groups by Scott-Knott test $(\mathrm{P}<0.05)$. ${ }^{1}$ Scientific names of the species and varieties are described in Material and Methods. ${ }^{2} \mathrm{~kg} \mathrm{SS}$ box ${ }^{-1} 40.8 \mathrm{~kg}$

Table 5. Annual and accumulated fruit production (P) from 2012 to 2014 (three initial crops), height (H), diameter (D), volume (V) in 2014, and mean production efficiency (P/V) in 2013-2014 of 'CNPMF-02 Persian' lime grafted onto nine rootstocks on the northern coast of the state of Bahia, Brazil.

\begin{tabular}{lcccccccc}
\hline Rootstocks' & P 2012 & P 2013 & $\begin{array}{c}\text { P 2014 } \\
\text { P 2012-2014 }\end{array}$ & H & $\begin{array}{c}\text { D } \\
\text { (kg/plant) ------------- }\end{array}$ & $\begin{array}{c}\text { V } \\
\left(\mathrm{m}^{3}\right)\end{array}$ & $\begin{array}{c}\text { P/V } \\
\left(\mathrm{kg} \mathrm{m}^{-3}\right)\end{array}$ \\
\hline CRC 1452 citrumelo & $20.5 \mathrm{~b}$ & $63.6 \mathrm{a}$ & $47.1 \mathrm{~b}$ & $131.3 \mathrm{~b}$ & $4.13 \mathrm{~b}$ & $4.7 \mathrm{a}$ & $42.6 \mathrm{a}$ & $1.8 \mathrm{a}$ \\
'Stanford' citrange & $16.6 \mathrm{~b}$ & $78.8 \mathrm{a}$ & $43.1 \mathrm{~b}$ & $138.7 \mathrm{~b}$ & $4.09 \mathrm{~b}$ & $4.7 \mathrm{a}$ & $42.0 \mathrm{a}$ & $2.3 \mathrm{a}$ \\
70-133 citrumelo & $32.3 \mathrm{a}$ & $67.4 \mathrm{a}$ & $53.1 \mathrm{~b}$ & $152.9 \mathrm{~b}$ & $4.03 \mathrm{~b}$ & $4.4 \mathrm{a}$ & $38.1 \mathrm{a}$ & $2.3 \mathrm{a}$ \\
Poncirus trifoliata & $23.4 \mathrm{~b}$ & $44.7 \mathrm{a}$ & $36.3 \mathrm{~b}$ & $104.5 \mathrm{~b}$ & $3.58 \mathrm{c}$ & $4.4 \mathrm{a}$ & $30.3 \mathrm{~b}$ & $1.9 \mathrm{a}$ \\
4570-A citrumelo & $9.1 \mathrm{~b}$ & $57.0 \mathrm{a}$ & $24.1 \mathrm{~b}$ & $90.3 \mathrm{~b}$ & $3.10 \mathrm{c}$ & $4.0 \mathrm{~b}$ & $20.9 \mathrm{~b}$ & $2.6 \mathrm{a}$ \\
'Cleopatra' mandarin & $13.4 \mathrm{~b}$ & $66.0 \mathrm{a}$ & $105.4 \mathrm{a}$ & $184.9 \mathrm{a}$ & $4.53 \mathrm{a}$ & $3.8 \mathrm{~b}$ & $36.8 \mathrm{a}$ & $3.2 \mathrm{a}$ \\
'Riverside' citrandarin & $45.7 \mathrm{a}$ & $89.1 \mathrm{a}$ & $92.6 \mathrm{a}$ & $227.5 \mathrm{a}$ & $4.89 \mathrm{a}$ & $4.1 \mathrm{~b}$ & $43.8 \mathrm{a}$ & $2.9 \mathrm{a}$ \\
'San Diego' citrandarin & $40.5 \mathrm{a}$ & $57.4 \mathrm{a}$ & $40.2 \mathrm{~b}$ & $138.2 \mathrm{~b}$ & $4.49 \mathrm{a}$ & $4.0 \mathrm{~b}$ & $38.4 \mathrm{a}$ & $1.7 \mathrm{a}$ \\
'Swingle' citrumelo (4475) & $21.8 \mathrm{~b}$ & $69.1 \mathrm{a}$ & $59.4 \mathrm{~b}$ & $150.4 \mathrm{~b}$ & $4.58 \mathrm{a}$ & $4.2 \mathrm{~b}$ & $43.3 \mathrm{a}$ & $2.4 \mathrm{a}$ \\
\hline CV (\%) & 42.6 & 35.1 & 27.1 & 25.5 & 9.1 & 7.9 & 22.7 & 29.1 \\
\hline
\end{tabular}

$\left.{ }^{*}\right)$ Averages followed by different letters in column belong to distinct groups by the Scott-Knott test $(\mathrm{P}<0.05){ }^{1}$ Scientific names of the species and varieties are described in Material and Methods. 
Table 6. Weight (W), length (L), diameter (D), peel thickness (P), juice yield (Y), number of seeds (N), titratable acidity (TA), soluble solids (SS), maturity index (SS/TA) and technological index (TI) of fruits of 'CNPMF-02 Persian' lime grafted onto nine rootstocks on the northern coast of the state of Bahia, Brazil, in the period 2013-2014.

\begin{tabular}{|c|c|c|c|c|c|c|c|c|c|c|}
\hline Rootstocks $^{1}$ & $\begin{array}{l}\text { W } \\
(\mathrm{g})\end{array}$ & $\begin{array}{c}\mathrm{L} \\
----(\mathrm{cm})\end{array}$ & $\begin{array}{c}\mathrm{D} \\
---- \\
\end{array}$ & $\begin{array}{c}\mathrm{P} \\
(\mathrm{mm}) \\
\end{array}$ & $\begin{array}{c}\mathrm{Y} \\
(\%)\end{array}$ & $\begin{array}{c}\mathrm{N} \\
\text { (unit) }\end{array}$ & $\begin{array}{l}\text { TA } \\
(\%) \\
\end{array}$ & $\begin{array}{c}\mathrm{SS} \\
\left({ }^{\circ} \mathrm{Brix}\right) \\
\end{array}$ & $\mathrm{SS} / \mathrm{TA}$ & $\mathrm{TI}^{2}$ \\
\hline CRC 1452 citrumelo & $136 \mathrm{a}$ & $6.6 \mathrm{a}$ & $5.9 \mathrm{a}$ & $3.5 \mathrm{a}$ & $30 \mathrm{a}$ & 0 & $6.13 \mathrm{a}$ & $9.7 \mathrm{a}$ & $1.57 \mathrm{a}$ & $1.29 \mathrm{a}$ \\
\hline 'Stanford' citrange & $128 \mathrm{~b}$ & $6.5 \mathrm{a}$ & $6.0 \mathrm{a}$ & $3.7 \mathrm{a}$ & $36 \mathrm{a}$ & 0 & $6.18 \mathrm{a}$ & $10.0 \mathrm{a}$ & $1.62 \mathrm{a}$ & $1.51 \mathrm{a}$ \\
\hline 70-133 citrumelo & $129 \mathrm{~b}$ & $6.5 \mathrm{a}$ & $5.9 \mathrm{a}$ & $3.4 \mathrm{a}$ & $36 \mathrm{a}$ & 0 & $6.39 \mathrm{a}$ & $9.8 \mathrm{a}$ & $1.53 \mathrm{a}$ & $1.52 \mathrm{a}$ \\
\hline Poncirus trifoliata & $123 \mathrm{~b}$ & $6.2 \mathrm{a}$ & $5.7 \mathrm{a}$ & $3.6 \mathrm{a}$ & $34 \mathrm{a}$ & 0 & $6.08 \mathrm{a}$ & $9.6 \mathrm{a}$ & $1.58 \mathrm{a}$ & $1.39 \mathrm{a}$ \\
\hline 4570-A citrumelo & $117 \mathrm{~b}$ & $6.3 \mathrm{a}$ & $5.8 \mathrm{a}$ & $3.8 \mathrm{a}$ & $34 \mathrm{a}$ & 0 & $5.62 \mathrm{a}$ & $9.8 \mathrm{a}$ & $1.74 \mathrm{a}$ & $1.43 \mathrm{a}$ \\
\hline 'Cleopatra' mandarin & $137 \mathrm{a}$ & $6.5 \mathrm{a}$ & $6.0 \mathrm{a}$ & $3.2 \mathrm{a}$ & $40 \mathrm{a}$ & 0 & $6.06 \mathrm{a}$ & $9.2 \mathrm{a}$ & $1.53 \mathrm{a}$ & $1.57 \mathrm{a}$ \\
\hline 'Riverside' citrandarin & $145 \mathrm{a}$ & $6.6 \mathrm{a}$ & $6.1 \mathrm{a}$ & $3.9 \mathrm{a}$ & 39 a & 0 & $6.28 \mathrm{a}$ & $9.3 \mathrm{a}$ & $1.48 \mathrm{a}$ & $1.51 \mathrm{a}$ \\
\hline 'San Diego' citrandarin & $142 \mathrm{a}$ & $7.0 \mathrm{a}$ & $6.2 \mathrm{a}$ & $3.7 \mathrm{a}$ & $41 \mathrm{a}$ & 0 & $6.99 \mathrm{a}$ & $9.6 \mathrm{a}$ & $1.63 \mathrm{a}$ & $1.65 \mathrm{a}$ \\
\hline 'Swingle' citrumelo (4475) & $125 \mathrm{~b}$ & $6.5 \mathrm{a}$ & $6.0 \mathrm{a}$ & $2.9 \mathrm{a}$ & $38 \mathrm{a}$ & 0 & $6.27 \mathrm{a}$ & $9.6 \mathrm{a}$ & $1.53 \mathrm{a}$ & $1.57 \mathrm{a}$ \\
\hline CV $(\%)$ & 8.0 & 4.2 & 2.5 & 13.6 & 11.4 & 0 & 4.4 & 3.6 & 6.3 & 9.1 \\
\hline
\end{tabular}

(*)Averages followed by different letters in column belong to distinct groups by Scott-Knott test $(\mathrm{P}<0.05) .{ }^{1}$ Scientific names of the species and varieties are described in Material and Methods. ${ }^{2} \mathrm{~kg} \mathrm{SS}$ box ${ }^{-1} 40.8 \mathrm{~kg}$
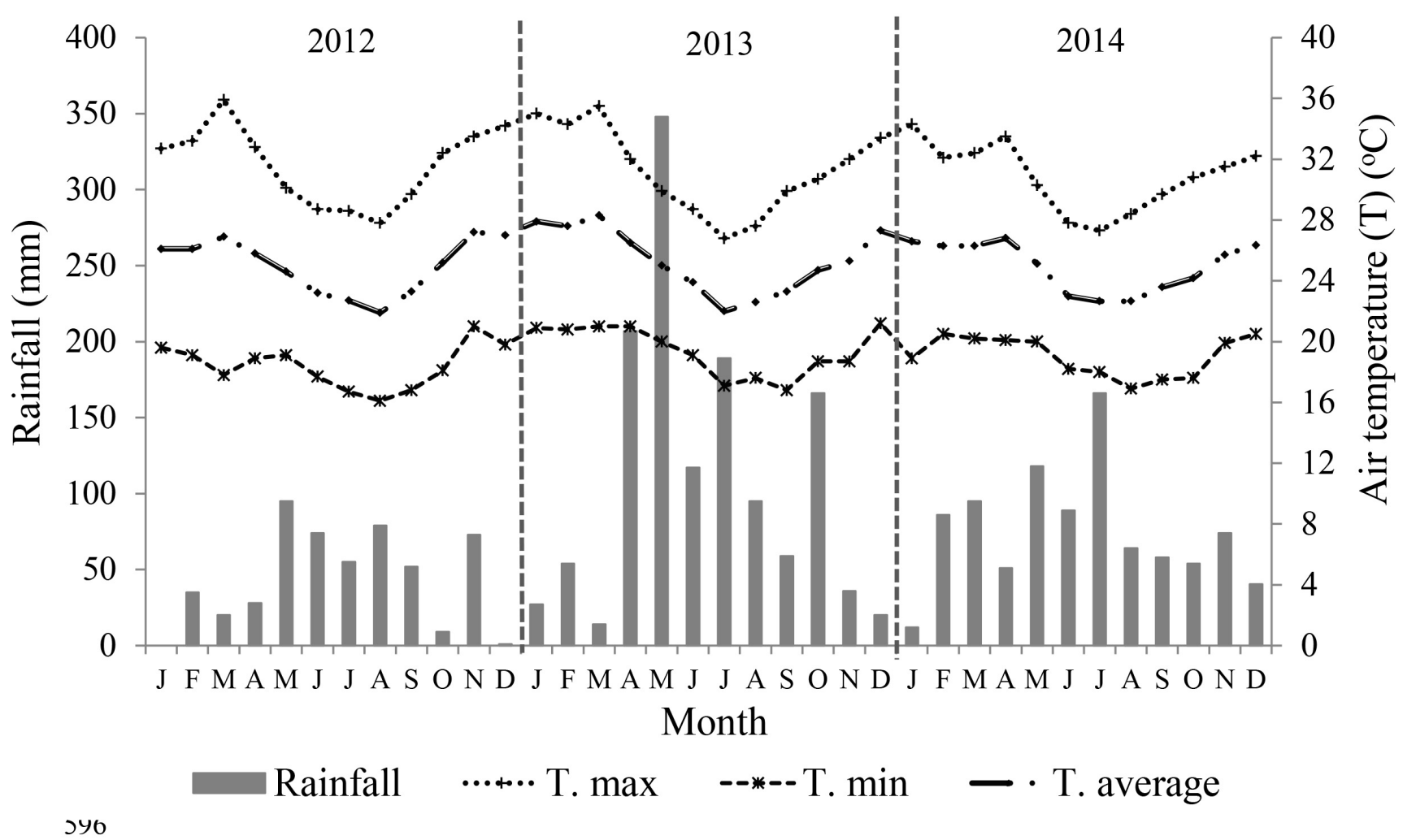

Figure 1. Monthly rainfall and mean maximum, average and minimum air temperatures at the experimental area in the municipality of Inhambupe, state of Bahia, Brazil, 2012-2014. 

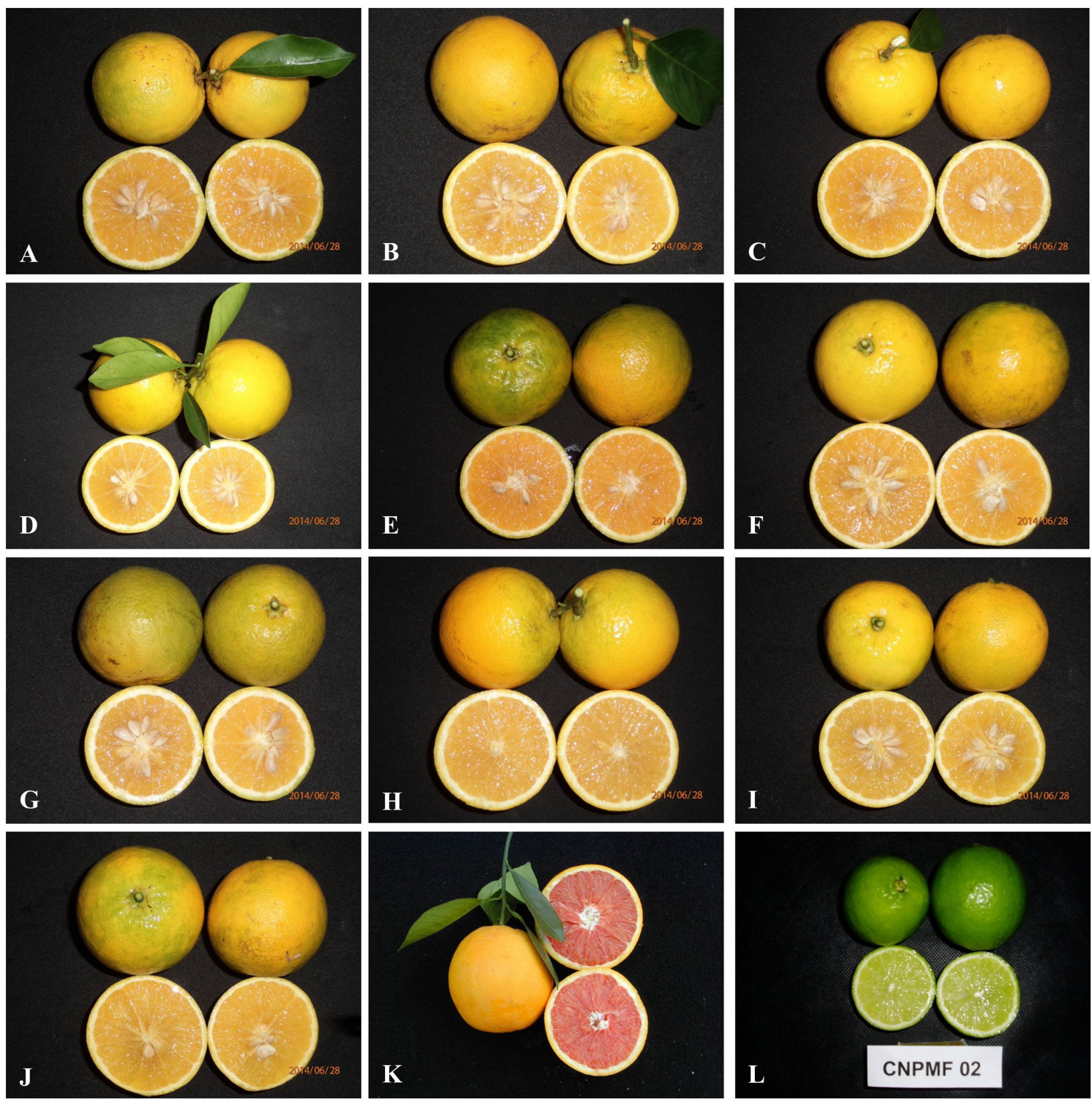

Figure 2. Typical mature fruits of 'Aquiri' (A), 'Biondo' (B), 'Jaffa' (C), 'Kona' (D), 'Melrosa' (E), 'Pineapple' (F), 'Russas CNPMF-03' (G), 'Salustiana' (H), 'Seleta Amarela' (I), 'Westin CNPMF' (J) and 'Cara Cara' (K) sweet oranges [Citrus sinensis (L.) Osbeck] and 'CNPMF-02 Persian' lime [C. latifolia (Yu. Tanaka) Tanaka] (L), evaluated at seven years of age on different rootstcks on the northern coast of the state of Bahia, Brazil, 2014.

\section{Conclusions}

'Pera CNPMF D-6', 'Westin CNPMF' and 'Salustiana' sweet oranges had fewer seeds per fruit, being the most appropriated for fresh fruit market among the studied varieties, in addition to greater production efficiency of 'Pera CNPMF D-6' and higher cumulative production of 'Salustiana' grafted onto 'San Diego' citrandarin.

'Florida' rough lemon and 'Volkamer' lemon induced higher cumulative production to 'Cara Cara' navel orange in the initial three crops, but tree size and fruit quality were not significantly influenced by any of the evaluated rootstocks.
'Cleopatra' mandarin and 'Riverside' citrandarin led to higher tree size and cumulative production, and heavier fruits of 'CNPMF-02 Persian' lime.

Based on their overall initial performance, all these scion and rootstock combinations have potential for cultivation on the northern coast of the state of Bahia and appear as an alternative to the prevalent 'Pera' sweet orange on 'Rangpur' lime combination. 


\section{Acknowledgements}

To the Coordination for the Improvement of Higher Education Personnel (CAPES), for granting scholarship for the first author; to the Agropecuária Gavião Ltda. and its team, for providing the experimental area and technical support; to the Embrapa Cassava \& Fruits by providing plant materials, fruit analysis and financial support; and to agronomist Magno Guimarães Santos for technical support.

\section{References}

ALMEIDA, C.O.; PASSOS, O.S. Citricultura brasileira: em busca de novos rumos, desafios e oportunidades na região Nordeste. Cruz das Almas: Embrapa Mandioca e Fruticultura, 2011. $160 \mathrm{p}$.

ALQUEZAR, B.; RODRIGO, M.J.; ZACARÍAS, L. Regulation of carotenoid biosynthesis during fruit maturation in the red-fleshed orange mutant Cara Cara. Phytochemistry, Amsterdam, v.69, n.10, p.1997-2007, 2008.

AZEVEDO, C.L.L. Sistema de produção de citros para o Nordeste. Cruz das Almas: Embrapa Mandioca e Fruticultura, 2003. (Sistema de Produção, 16). Disponível em: $\leq$ https://sistemasdeproducao.cnptia.embrapa.br/ FontesHTML/Citros/CitrosNordeste/>. Acesso em: maio 2017.

BREMER NETO, H.; MOURÃO FILHO, F.A.A.; STUCHI, E.S.; ESPINOZA-NÚÑEZ, E.; CANTUARIASAVILÉS, T.E. The horticultural performance of five 'Tahiti' lime selections grafted onto 'Swingle' citrumelo under irrigated and non-irrigated conditions. Scientia Horticulturae, Wageningen, v.150, p.181-186, 2013.

CANTUARIAS-AVILÉS, T.E.; MOURÃO FILHO, F.A.A.; STUCHI, E.S.; SILVA, S.R.; ESPINOZANÚÑEZ, E.; BREMER NETO, H. Rootstocks for high fruit yield and quality of 'Tahiti' lime under rain-fed conditions. Scientia Horticulturae, Wageningen, v.142, p.105- 111, 2012.

CARVALHO, H.W.L.; SOARES FILHO, W.S.; MARTINS, C.R.; PASSOS, O.S.; TEODORO, A.V.; CARVALHO, L.M.; GIRARDI, E.A.; GESTEIRA, A.S.; CARDOSO, B.T.; OLIVEIRA, T.R.A.; MARQUES, M.G.; MOITINHO, A.C.; SANTOS, D.L.; PORTO, E.S. Desempenho agronômico da laranjeira 'sincorá' sobre diferentes porta-enxertos em áreas de Tabuleiros Costeiros do Estado de Sergipe. Aracaju: Embrapa Tabuleiros Costeiros, 2015a. 10 p. (Comunicado Técnico, 171).
CARVALHO, H.W.L.; SOARES FILHO, W.S.; MARTINS, C.R.; PASSOS, O.S.; TEODORO, A.V.; CARVALHO, L.M.; GIRARDI, E.A.; GESTEIRA, A.S.; CARDOSO, B.T.; OLIVEIRA, T.R.A.; MARQUES, M.G.; MOITINHO, A.C.; SANTOS, D.L.; PORTO, E.S.ARAUJO, S.B. Desempenho da laranjeira 'Pineapple' sobre diferentes porta-enxertos em áreas de Tabuleiros Costeiros de Sergipe. Aracaju: Embrapa Tabuleiros Costeiros, 2015b. 9 p. (Documentos ,174).

CARVALHO, H.W.L.; SOARES FILHO, W.S.; MARTINS, C.R.; PASSOS, O.S.; TEODORO, A.V.; CARVALHO, L.M.; GIRARDI, E.A.; GESTEIRA, A.S.; CARDOSO, B.T.; OLIVEIRA, T.R.A.; MARQUES, M.G.; MOITINHO, A.C.; SANTOS, D.L.; PORTO, E.S.ARAUJO, S.B. Desempenho da laranjeira 'Valência Tuxpan' sobre diferentes porta-enxertos em Áreas de Tabuleiros Costeiros do Estado de Sergipe. Aracaju: Embrapa Tabuleiros Costeiros, 2015c.10 p. (Comunicado Técnico, 181).

CARVALHO, L.M.; CARVALHO, H.W.L.; SOARES FILHO, W.S.; MARTINS, C.R.; PASSOS, O.S. Porta-enxertos promissores, alternativos ao limoeiro 'Cravo', nos Tabuleiros Costeiros de Sergipe. Pesquisa Agropecuária Brasileira, Brasília, DF, v.51, n.2, p.132141, 2016.

CASTLE, W.S., BALDWIN, J.C. Young-tree performance of juvenile sweet orange scions on Swingle citrumelo rootstock. HortScience, Alexandria, v.46, n.4, p.541-552, 2011.

CINTRA, F.L.D. Caracterização da região produtora: solo e clima. In: MELO, M.B.; SILVA, L.M.S. (Ed.). Aspectos técnicos dos citros em Sergipe. Aracaju: Embrapa Tabuleiros Costeiros, 2007. p.11-19.

COELHO, E.F.; COELHO FILHO M.A.; SIMÕES, W.L.; COELHO, Y.S. Irrigação em citros nas condições do Nordeste do Brasil. Revista Laranja, Cordeirópolis, v.27, n.2, p.297-320, 2006.

ESPINOZA-NUÑEZ, E.; MOURÃO FILHO, F.A.A.; STUCHI, E.S.; CANTUARIAS-AVILÉS, T.E.; DIAS, T.S. Performance of 'Tahiti' acid lime on twelve rootstocks under irrigated and non-irrigated conditions. Scientia Horticulturae, Amsterdam, v.129, p.227-231, 2011.

FRANÇA, N.O.; AMORIM, M.S.; GIRARDI, E.A.; PASSOS, O.S.; SOARES FILHO, W.S. Performance of 'Tuxpan Valencia' sweet orange grafted onto 14 rootstocks in northern Bahia, Brazil. Revista Brasileira de Fruticultura, Jaboticabal, v.38, n.4, e-684, 2016. 
GAYET, J.P.; SALVO FILHO, A. Colheita e beneficiamento.In: MATTOS JUNIOR, D.; DE NEGRI, J.D.; FIGUEIREDO, J.O. Lima ácida Tahiti. Campinas: Instituto Agronômico, 2003. p.147-162.

IBGE. IBGE Estados Bahia lavoura permanente 2015. Disponível em: $<$ http://www.ibge.gov.br/estadosat/temas. php? sigla $=$ ba\&tema $=$ lavourapermanente $2015>$. Acesso em: 07 maio 2017.

LEDO, A.S.; LEDO, F.J.S.; RITZINGER, R.; CUNHA SOBRINHO, A.P. Porta-enxertos para laranjeiras-doces (Citrus sinensis (L.) Osb.) em Rio Branco, Acre. Pesquisa Agropecuária Brasileira, Brasília, DF, v.34, n.7, p.12111216, 1999.

MARTINS, C.R.; CARVALHO, H.W.L.; TEODORO, A.V.; SOARES FILHO, W.S.; PASSOS, O.S. Agronomical performance of citrus scion cultivars grafted on Rangpur lime in north-eastern Brazil. Australian Journal of Crop Science, Sydney, v.10, n.1, p.16-23, 2016.

MEDEIROS, R.C.; MUSSER, R.S.; SILVA, M.M.; SANTOS, J.P.O.; NASCIMENTO JUNIOR, I.R. Análise exploratória das características morfológicas e qualitativas de variedades de laranjeiras de mesa da coleção em Brejão - PE. Revista Brasileira Fruticultura, Jaboticabal, v.35, n.2, p.500-507, 2013.

OLIVEIRA, R.P.; UENO, B.; SCIVITTARO, W.B.; SANTOS, V.X.; TIMM, F.C. 'Cara Cara' laranja de polpa vermelha. Pelotas: Embrapa Clima Temperado, 2013. 2 p.

PASSOS, O.S.; SOARES FILHO, W.S.; BARBOSA, C.J.; CUNHA SOBRINHO, A.P. Clones da laranjeira 'de Russas'. Cruz das Almas: Embrapa Mandioca e Fruticultura, 2013. 2 p.

PASSOS, O.S.; SOARES FILHO, W.S.; CUNHA SOBRINHO, A.P.; SOUZA, A.S.; SANTOS, L.C.; PEIXOUTO, L.S. Banco ativo de germoplasma de citros da Embrapa Mandioca e Fruticultura Tropical: passado, presente e futuro. Cruz das Almas: Embrapa Mandioca e Fruticultura, 2007. 61p. (Documentos, 163).

PÉREZ, F.M.R.; VÉLEZ, A.G.; MACCHIAVELLI, R. Production and fruit quality of the 'Cara Cara' variety of sweet orange in three localities in Puerto Rico. In: ANNUAL MEETING OF THE INTERAMERICAN SOCIETY FOR TROPICAL AGRICULTURE, 52., 2006, San Juan. Proceedings... San Juan: University of Puerto Rico, 2006. p.51-52. Disponível em: $\leq$ http:// iasth.org/arquivos/libroisth_2006.pdf $>$. Acesso em: 07 maio 2017.
POMPEU JUNIOR, J. Porta-enxertos. In: MATTOS JUNIOR, D.; PIO, R.M.; DE NEGRI, J.D.; POMPEU JUNIOR, J. (Ed.). Citros. Campinas: Instituto Agronômico de Campinas: Fundag, 2005. p.63-104.

POZZAN, M.; TRIBONI, H.R. Colheita e qualidade do fruto. In: MATTOS JUNIOR, D.; PIO, R.M.; DE NEGRI, J.D.; POMPEU JUNIOR, J. (Ed.). Citros. Campinas: Instituto Agronômico de Campinas: Fundag, 2005. p.799822.

PRUDENTE, R.M.; SILVA, L.M.S.; CUNHA SOBRINHO, A.P.da. Comportamento da laranjeira Pera D6 sobre cinco porta-enxertos em ecossistema de tabuleiros costeiros, Umbaúba-SE. Revista Brasileira de Fruticultura, Jaboticabal, São Paulo, v.26, n.1, p.110-112, 2004.

SANTOS, M.G.; SOARES FILHO, W.S.; GIRARDI, E.A.; GESTEIRA, A.S.; PASSOS, O.S.; FERREIRA, C.F. Initial horticultural performance of nine 'Persian' lime selections grafted onto Swingle citrumelo. Scientia Agricola, Piracicaba, v.73, n.2, p.109-114, 2016.

SOARES FILHO, W.S., CUNHA SOBRINHO, A.P., PASSOS, O.S. Porta-enxertos para laranja 'Bahia', na região de Cruz das Almas, BA. Pesquisa Agropecuária Brasileira, Brasília, DF, v.16, n.4, p.501 -505, 1981.

STENZEL, N.M.C.; NEVES, C.S.V.J. Rootstocks for 'Tahiti' lime. Scientia Agricola, Piracicaba, v.61, n.2, p.151-155, 2004.

STUCHI, E.S.; MARTINS, A.B.G.; LEMO, R.R.e CANTUARIAS-AVILES, T. Fruit quality of 'Tahiti' lime (Citrus latifolia Tanak) grafted on twelve different rootstocks. Revista Brasileira de Fruticultura, Jaboticabal, v.31, n.2, p.454-460, 2009.

URRUTIA, V.M.M.; ESPARZA, E.Z.; GONZÁLEZ, M.M.R.; ZAMORA, O.P.; SANTOS, M.O.; WILLIAMS, T.; RODRÍGUEZ, S.B. Fenología, eficiencia productiva y calidad de fruta de cultivares de naranjo en el trópico seco de México. Revista Fitotecnia Mexicana, Chapingo, v.30, n.2, p.133-143, 2007.

WRIGHT, G.C. Evaluation of ten navel orange (Citrus sinensis L.Osbeck) selections under Arizona desert conditions. In: INTERNATIONAL HORTICULTURAL CONGRESS \& EXHIBITION, 27., 2006, Seoul. Abstracts... Seoul: The Korean Society for Horticultural Science, 2007. p.449. 